\title{
An Intercomparison of Measurement Systems for Vapor and Particulate Phase Concentrations of Formic and Acetic Acids
}

\author{
William C. Keene, ${ }^{1}$ Robert W. Talbot, ${ }^{2,8}$ Meinrat O. Andreae, ${ }^{3,9}$ Kristene Beecher, ${ }^{2}$ \\ Harold Berresheim, ${ }^{3,10}$ Mark Castro, ${ }^{1}$ J. Carl Farmer, ${ }^{4}$ James N. Galloway, ${ }^{1}$ \\ Michael R. Hoffmann, ${ }^{5}$ Shao-Meng Li, ${ }^{3}$ John R. Maben, ${ }^{1}$ J. William Munger, ${ }^{5}$ \\ Richard B. Norton, ${ }^{6}$ Alexander A. P. Pszenny, ${ }^{1,11}$ Hans Puxbaum, ${ }^{7}$ \\ Hal Westberg, ${ }^{4}$ and Wilfried Winiwarter ${ }^{7}$
}

\begin{abstract}
During June 1986, eight systems for measuring vapor phase and four for measuring particulate phase concentrations of formic acid $(\mathrm{HCOOH})$ and acetic acid $\left(\mathrm{CH}_{3} \mathrm{COOH}\right)$ were intercompared in central Virginia. $\mathrm{HCOOH}$ and $\mathrm{CH}_{3} \mathrm{COOH}$ vapors were sampled by condensate, mist, Chromosorb $103 \mathrm{GC}$ resin, $\mathrm{NaOH}$-coated annular denuders, $\mathrm{NaOH}$ impregnated quartz filters, $\mathrm{K}_{2} \mathrm{CO}_{3}$ and $\mathrm{Na}_{2} \mathrm{CO}_{3}$ impregnated cellulose filters, and Nylasorb membranes. Atmospheric aerosol was collected on Teflon and Nuclepore filters using both hi-vol and lo-vol systems to measure particulate phase concentrations. Samples were collected during 31 discrete day and night intervals of $0.5-2$ hour duration over a 4-day period. Performance of the mist chamber and $\mathrm{K}_{2} \mathrm{CO}_{3}$ impregnated filter techniques were also evaluated using zero air and ambient arr spiked with $\mathrm{HCOOH}_{\mathrm{g}}, \mathrm{CH}_{3} \mathrm{COOH}_{\mathrm{g}}$, and formaldehyde $\left(\mathrm{CH}_{2} \mathrm{O}_{\mathrm{g}}\right)$ from permeation sources. Results of this intercomparison show significant systematic and episodic artifacts among many currently deployed measurement systems for $\mathrm{HCOOH}_{\mathrm{s}}$ and $\mathrm{CH}_{3} \mathrm{COOH}_{\mathrm{g}}$. The spiking experiments revealed no significant interferences for the mist chamber technique and results generated by the mist chamber and denuder techniques were statistically indistinguishable. The condensate technique showed general agreement with the mist chamber and denuder methods, but episodic bias between these systems was inferred from large and significant differences observed during the first day of sampling. Nylasorb membranes are unacceptable for collecting carboxylic acid vapors as they did not retain $\mathrm{HCOOH}_{\mathrm{g}}$ and $\mathrm{CH}_{3} \mathrm{COOH}_{\mathrm{g}}$ quantitatively. Strong base impregnated filter and GC resin sampling techniques are prone to large positive interferences apparently resulting, in part, from reactions involving $\mathrm{CH}_{2} \mathrm{O}_{\mathrm{g}}$ to generate $\mathrm{HCOOH}$ and $\mathrm{CH}_{3} \mathrm{COOH}$ subsequent to collection. Significant bias presumably associated with differences in postcollection handling was observed for particulate phase measurements by participating groups. Analytical bias did not contribute significantly to differences in vapor and particulate phase measurements.
\end{abstract}

\section{INTRODUCTION}

Formic acid $(\mathrm{HCOOH})$ and acetic acid $\left(\mathrm{CH}_{3} \mathrm{COOH}\right)$ are major chemical constituents of precipitation [e.g., Keene and Galloway, 1986] and cloud water [e.g., Weathers et al., 1988]. Relative to the large data bases of aqueous phase observations,

\footnotetext{
'Department of Environmental Sciences, University of Virginia, Charlottesville, Virginia.

${ }^{2}$ Atmospheric Sciences Divisıon, NASA Langley Research Center, Hampton, Virginia.

${ }^{3}$ Department of Oceanography, Florida State University, Tallahassee, Florida.

${ }^{4}$ Laboratory for Atmospheric Research, Washington State University, Pullman, Washington.

${ }^{5}$ Environmental Engineering Sciences, California Instıtute of Technology, Pasadena, California.

${ }^{6}$ Aeronomy Laboratory, National Oceanic and Atmospheric Administration, Boulder, Colorado.

${ }^{7}$ Institute for Analytical Chemistry, Technical University of Vienna, Vienna, Austria.

${ }^{8}$ Now at Complex Systems Research Center, University of New Hampshire, Durham, New I lampshire.

${ }^{9}$ Now at Max-Planck-Instıtut for Chemıstry, Mainz, Federal Republic of Germany.

${ }^{10}$ Now at School of Geophysical Sciences, Georgia Institute of Technology, Atlanta, Georgia.

"Now at Atlantic Oceanographic and Meteorological Laboratories, National Oceanic and Atmospheric Administration, Miami, Florida.

Copyright 1989 by the American Geophysical Union.

Paper number 89JD00241.

0148-0227/89/89JD-00241\$05.00
}

however, few measurements of these acids in the vapor and particulate phase have been reported [e.g., Andreae et al., 1988; Dawson and Farmer, 1988; Talbot et al., 1988]. Theoretical considerations suggest that $\mathrm{HCOOH}$ and $\mathrm{CH}_{3} \mathrm{COOH}$ may be involved in potentially important atmospheric chemical transformation sequences [e.g., Chameides and Davis, 1983; Jacob, 1986; Jacob and Wofsy, 1988], and this realization has stimulated investigators to initiate multiphase sampling for these constituents. A variety of measurement techniques for determining vapor and particulate phase concentrations of $\mathrm{HCOOH}$ and $\mathrm{CH}_{3} \mathrm{COOH}$ are currently in use, but few have been rigorously tested to assess potential artifacts associated with sampling and analysis. Intercomparing field measurements of atmospheric constituents obtained at a common place and time, but using different types of measurement systems has proved to be a valuable tool for identifying such artifacts [e.g., Hoell et al., 1985; Mulawa and Cadle, 1985; Anlauf et al., 1985; Fehsenfeld et al., 1987]. Between June 10, and June 13, 1986, a number of investigators from seven different research groups gathered in Charlottesville, Virginia, and intercompared eight measurement techniques for vapor phase and four particulate phase concentrations of $\mathrm{HCOOH}$ and $\mathrm{CH}_{3} \mathrm{COOH}$. This paper reports the results of that intercomparison.

\section{Methods}

\section{Sampling and Analytical Systems}

The methods of collection, conditions of sample storage, extraction procedures and analytical techniques for measurement systems of participating groups are summarized in 
Tables 1 and 2. Vapor phase species were sampled by 8 different techniques. Washington State University (WSU) collected soluble gases using the condensate technique as described by Farmer and Dawson [1982]. The University of Virginia (UVA) operated two collection systems for vapor. UVA 1 modified a technique described by Haynes [1979] to remove carboxylic acids from an airstream pulled through Chromosorb $103 \mathrm{GC}$ resin packed in $4.76 \mathrm{~mm}$ ID Tygon columns. UVA 2 collected vapor on two tandem Nylon membranes mounted on separate stages of polycarbonate cassettes. Peaks for carboxylic acids had been observed previously during ion chromatograph analysis of extracts from Nylon membranes used to collect $\mathrm{HNO}_{3}$ vapor. In response to this observation, it was decided to include the UVA 2 system in the intercomparison, despite the fact that its performance in terms of specificity or collection efficiency had not been previously tested. Florida State University (FSU) collected acidic gases from an air stream pulled through $25 \mathrm{~mm}$ cellulose paper filters which were impregnated with $1.8 \mathrm{M} \mathrm{K}_{2} \mathrm{CO}_{3}$ and mounted in polycarbonate cassettes. The California Institute of Technology (CIT) operated a similar system consisting of $47 \mathrm{~mm}$ quartz fiber filters which were impregnated with $0.025 \mathrm{M} \mathrm{NaOH}$ and mounted in polycarbonate cassettes. The NOAA Aeronomy Laboratory (NOAA) collected acidic gases on $90 \mathrm{~mm}$ cellulose paper filters which were impregnated with $0.02 \mathrm{M}$ $\mathrm{Na}_{2} \mathrm{CO}_{3}$ and mounted in polycarbonate cassettes. The NASA Langley Research Center (NASA) collected watersoluble trace gases with a mist chamber as described by Cofer et al. [1985] and Talbot et al. [1988]. The Technical University of Vienna (TUW) collected acidic vapor using annular denuder tubes coated with $0.10 \mathrm{M} \mathrm{NaOH}$ as described by Rosenberg et al. [1988]. With the exception of the WSU's condensate sampler and TUW's denuder tubes, both of which exclude particles by the nature of collection, all of the above systems incorporated upstream prefilters to remove particles from the air stream prior to collection of vapor phase carboxylic acids.

Data from four measurement systems for particulate phase carboxylic acids were also intercompared. Because of short sampling times ( $\sim 1$ hour), low sampling rates (Table 1 ), and low ambient concentrations (see Results and Discussion), little particulate material was deposited on the upstream filters of the previously described samplers for vapor, and consequently most of these systems had inadequate resolution for quantifying particulate phase concentrations. Only NOAA generated enough observations above system detection limits to statistically compare with results from the hi-vol sampling systems for particles operated by UVA 1 and NASA. The two hi-vol systems collected particles on 102 $\mathrm{mm}, 2.0 \mu \mathrm{m}$ Teflon (Zefluor) filters mounted in open face stainless steel housings. In addition to the above three systems, NASA operated a low-vol sampling system for particles consisting of stacked $47 \mathrm{~mm}$ filters mounted in polycarbonate cassettes. The front filter for coarse particles was an $8.0 \mu \mathrm{m}$ Nuclepore filter followed by a $2.0-\mu \mathrm{m}$ Teflon (Zefluor) filter for fine particles. The aerodynamic cutoff diameter between the two particle fractions was $1.5 \mu \mathrm{m}$ [John et al., 1983]. To obtain sufficient sample for analysis, this system was operated for time periods ranging from 2 to 6 hours.

The performance of each analytical laboratory was intercompared with blind audit solutions which bracketed the typical concentration ranges for intercomparison samples. These solutions were prepared by UVA, treated with $\mathrm{CHCl}_{3}$ to prevent microbial transformation [Keene et al., 1983], and distributed to each group during the intercomparison.

Mean detection limits (Table 3 ) were estimated from the combined uncertainties associated with samples, field blanks, and sampling rates, following in part the procedures recommended by Currie [1968]. These estimates are based on the assumption that the standard error is approximately constant for each system in the range between 0 and the calculated detection limit. We further assume that the standard deviation for samples $\left(S_{S}\right)$ at the detection limit is approximately equal to the standard deviation for replicate field blanks $\left(S_{B}\right)$ run during the course of the intercomparison. The overall uncertainties $\left(S_{0}\right)$ associated with samples and blanks can be combined as follows:

$$
S_{0}=\left(S_{S}^{2}+S_{B}^{2}\right)^{1 / 2}
$$

but

$$
S_{S}=S_{B}
$$

so

$$
S_{0}=\left(2 S_{B}^{2}\right)^{1 / 2}
$$

Uncertainties in sampling rates $\left(U_{R}\right)$ were estimated in units of percent from calibration or from manufacturer's specifications. At the detection limit, this uncertainty can be approximated in units of nmol by

$$
S_{V}=U_{R} S_{0}
$$

The mean detection limit (MDL) at $95 \%$ confidence can then be expressed as

$$
\mathrm{MDL}=1.96 * \frac{\left(S_{0}^{2}+S_{V}^{2}\right)^{1 / 2}}{V_{S}}
$$

where $V_{S}$ is the mean sample volume.

We recognize that the procedure for including flow uncertainties in overall uncertainties represents an approximation and is not a rigorous statistical formulation. We believe, however, that this approach does represent a reasonable quantitative estimate of the detection limit.

\section{Experimental Design}

Sampling apparatus were operated on the southeastern roof of the Environmental Sciences Building (Clark Hall) at the University of Virginia in Charlottesville, Virginia, between June 10, and June 13, 1986. Inlets were positioned at a height of $1-1.5 \mathrm{~m}$ above the roof surface $(20 \mathrm{~m}$ above ground level) at the locations indicated on Figure 1. Exhaust from the pumps was collected in a common manifold and discharged on the opposite (northwest) side of the building approximately $60 \mathrm{~m}$ distance and $20 \mathrm{~m}$ below the sample inlets. Samples were collected simultaneously during 31 discrete intervals ranging from 0.5 to 2 hours in duration. The TUW denuder system required somewhat longer sampling times for adequate resolution, and therefore their samples were collected over longer time intervals ( 2 hours) relative to most other systems (typically 1 hour). To ensure that the same air parcels were sampled, air flow through the denuder tubes was stopped when the other systems were shut off for servicing. To minimize possible effects of phase 
TABLE 1. Collection Systems and Sample Storage

\begin{tabular}{|c|c|c|c|c|c|c|}
\hline $\begin{array}{l}\text { Principal } \\
\text { Investigator }\end{array}$ & Organization & Code & $\begin{array}{l}\text { Collection of } \\
\text { Particles }\end{array}$ & Collection of Vapor & $\begin{array}{c}\text { Mean } \\
\text { Sampling } \\
\text { Rate (SLPM) }\end{array}$ & $\begin{array}{c}\text { Sample Storage Prior to } \\
\text { Analysis }\end{array}$ \\
\hline $\begin{array}{l}\text { Carl } \\
\text { Farmer }\end{array}$ & $\begin{array}{l}\text { Washington State } \\
\text { University }\end{array}$ & WSU & not collected & $\begin{array}{l}\text { Condensate [Farmer } \\
\text { and Dawson, 1982] }\end{array}$ & $10-20$ & $\begin{array}{l}\text { Vapor: condensate was } \\
\text { treated with } 5 \mathrm{~mL} \mathrm{CHCl} \\
\text { and refrigerated in glass } \\
\text { vial at } 5^{\circ} \mathrm{C} \text {. }\end{array}$ \\
\hline $\begin{array}{l}\text { William } \\
\text { Keene }\end{array}$ & $\begin{array}{l}\text { University of } \\
\text { Virginia }\end{array}$ & $\begin{array}{c}\text { UVA } \\
1\end{array}$ & $\begin{array}{l}102 \mathrm{~mm} \\
\text { Teflon } \\
\text { filters }(2.0 \\
\mu \mathrm{m} \\
\text { Zefluor) }\end{array}$ & $\begin{array}{l}50 \text { mg } 20-40 \text { mesh }^{\mathrm{C}} \text { Chromosorb }{ }^{\mathrm{R}} 103 \\
\text { GC resin [Haynes, } \\
\text { 1979] packed in } \\
4.76 \mathrm{~mm} \text { ID Tygon } \\
\text { columns. Particles } \\
\text { were removed with } \\
\text { an upstream } 47 \mathrm{~mm} \\
\text { Teflon filter ( } 2.0 \mu \mathrm{m} \\
\text { Zefluor). }\end{array}$ & $\begin{array}{l}\text { particles, } 580 . \\
\text { vapor, } 10.5\end{array}$ & $\begin{array}{l}\text { Particles: filters were } \\
\text { removed from holders, } \\
\text { placed in glass vials, and } \\
\text { frozen at }-4^{\circ} \mathrm{C} \text {. } \\
\text { Vapor: cartridges were stored } \\
\text { in } 2 \text { polyethylene bags and } \\
\text { frozen at }-4^{\circ} \mathrm{C} \text {. }\end{array}$ \\
\hline $\begin{array}{l}\text { Meinrat } \\
\text { Andreae }\end{array}$ & $\begin{array}{r}\text { Florida State } \\
\text { University }\end{array}$ & FSU & not analyzed & $\begin{array}{l}25 \text { mm cellulose filters } \\
\text { (Schleicher and } \\
\text { Schuell) } \\
\text { impregnated with } \\
1.8 \mathrm{M} \mathrm{K}_{2} \mathrm{CO}_{3} \text { in } \\
10 \% \text { glycerol: } \mathrm{H}_{2} \mathrm{O} \\
\text { solution. Particles } \\
\text { were removed with } \\
\text { an upstream } 47 \mathrm{~mm} \\
\text { Teflon filter }(2.0 \mu \mathrm{m} \\
\text { Zefluor). }\end{array}$ & 20. & $\begin{array}{l}\text { Vapor: filters were extracted, } \\
\text { treated with } 100 \mu \mathrm{L} \\
\mathrm{CHCl}_{3} \text {, and analyzed } \\
\text { immediately. }\end{array}$ \\
\hline $\begin{array}{l}\text { William } \\
\text { Munger }\end{array}$ & $\begin{array}{l}\text { California } \\
\text { Institute of } \\
\text { Technology }\end{array}$ & CIT & not analyzed & $\begin{array}{l}47 \text { mm quartz filters } \\
\text { (Whatman QMA) } \\
\text { impregnated with } 1 \\
\text { mL of } 0.025 \mathrm{M} \\
\text { NaOH in ethanol. } \\
\text { Particles were } \\
\text { removed with an } \\
\text { upstream } 47 \mathrm{~mm} \\
\text { Teflon filter }(1.0 \mu \mathrm{m} \\
\text { Zefluor). }\end{array}$ & 10.6 & $\begin{array}{l}\text { Vapor: filters were removed } \\
\text { from holders, placed in } \\
\text { plastic petri dishes, and } \\
\text { frozen at }-4^{\circ} \mathrm{C} \text {. }\end{array}$ \\
\hline $\begin{array}{l}\text { Richard } \\
\text { Norton }\end{array}$ & $\begin{array}{l}\text { Aeronomy } \\
\text { Laboratory }\end{array}$ & NOAA & $\begin{array}{l}90 \mathrm{~mm} \\
\text { Teflon } \\
\text { filters (1.0 } \\
\mu \mathrm{m} \\
\text { Zefluor) }\end{array}$ & $\begin{array}{l}90 \mathrm{~mm} \text { cellulose } \\
\text { (Whatman } 41 \text { ) } \\
\text { impregnated with } \\
0.02 \mathrm{M} \mathrm{Na} \mathrm{CO}_{3} \text { in } \\
10 \% \text { glycerol: } \mathrm{H}_{2} \mathrm{O} \\
\text { solution }\end{array}$ & 85. & $\begin{array}{l}\text { Filters were removed from } \\
\text { holders, placed in } \\
\text { polyethylene bags, and } \\
\text { refrigerated at } 4^{\circ} \mathrm{C} \text {. }\end{array}$ \\
\hline $\begin{array}{l}\text { Alexander } \\
\text { Pszenny }\end{array}$ & $\begin{array}{l}\text { University of } \\
\text { Virginia }\end{array}$ & $\begin{array}{l}\text { UVA } \\
2\end{array}$ & $\begin{array}{l}47 \mathrm{~mm} \\
\text { Teflon } \\
\text { filters }(2.0 \\
\mu \mathrm{m} \\
\text { Zefluor })\end{array}$ & $\begin{array}{l}\text { Tandem } 47 \mathrm{~mm} \text { Nylon } \\
\text { membranes } \\
\text { (Nylasorb) }\end{array}$ & 52.5 & $\begin{array}{l}\text { Filters were removed from } \\
\text { holders, placed in plastic } \\
\text { petri dishes, stored in } 2 \\
\text { polyethylene bags, and } \\
\text { frozen at }-4^{\circ} \mathrm{C} \text {. }\end{array}$ \\
\hline $\begin{array}{l}\text { Robert } \\
\text { Talbot }\end{array}$ & $\begin{array}{l}\text { Langley } \\
\text { Research } \\
\text { Center }\end{array}$ & NASA & $\begin{array}{l}47 \mathrm{~mm} \\
\text { Nuclepore } \\
\text { filters ( } 8.0 \\
\mu \mathrm{m}) ; \\
47 \mathrm{~mm} \\
\text { Teflon } \\
\text { filters (2.0 } \\
\mu \mathrm{m} \\
\text { Zefluor); } \\
102 \mathrm{~mm} \\
\text { Teflon } \\
\text { filters (2.0 } \\
\mu \mathrm{m} \\
\text { (Zefluor) }\end{array}$ & $\begin{array}{l}\text { Mist chamber [Cofer } \\
\text { et al., 1985]. } \\
\text { Particles were } \\
\text { removed with an } \\
\text { upstream } 47 \mathrm{~mm} \\
\text { Teflon filter }(2.0 \mu \mathrm{m} \\
\text { Zefluor) }\end{array}$ & $\begin{array}{l}\text { particles } \\
\text { (stacked), } \\
20 . \\
\text { particles } \\
\text { (hi-vol), } \\
580 . \\
\text { vapor, } 7 .\end{array}$ & $\begin{array}{l}\text { Particles: filters were } \\
\text { removed from holders, } \\
\text { placed in a polyethylene } \\
\text { bag, and stored in dark at } \\
\text { room temperature. } \\
\text { Vapor: solution was treated } \\
\text { with } 50 \mu \mathrm{L} \mathrm{CHCl}_{3} \text { and } \\
\text { analyzed immediately. }\end{array}$ \\
\hline $\begin{array}{l}\text { Wilfried } \\
\text { Winiwarter }\end{array}$ & $\begin{array}{l}\text { Technical } \\
\text { University of } \\
\text { Wien (Vienna) }\end{array}$ & TUW & not analyzed & $\begin{array}{l}\text { Two anular denuders } \\
\text { (in series) each } \\
\text { coated with } 4 \mathrm{~mL} \\
\text { of } 0.10 \mathrm{M} \mathrm{NaOH} \text { in } \\
90 \% \text { methanol }\end{array}$ & 10. & $\begin{array}{l}\text { Vapor: } \mathrm{HCOOH} \text { in untreated } \\
\text { eluent was measured } \\
\text { immediately after } \\
\text { collection. } \mathrm{CH}_{3} \mathrm{COOH} \text { was } \\
\text { measured within } 2 \text { weeks in } \\
\text { eluent treated with } 50 \mu \mathrm{L} \\
\mathrm{CHCl}_{3} \text { and refrigerated at } \\
4^{\circ} \mathrm{C} \text {. }\end{array}$ \\
\hline
\end{tabular}




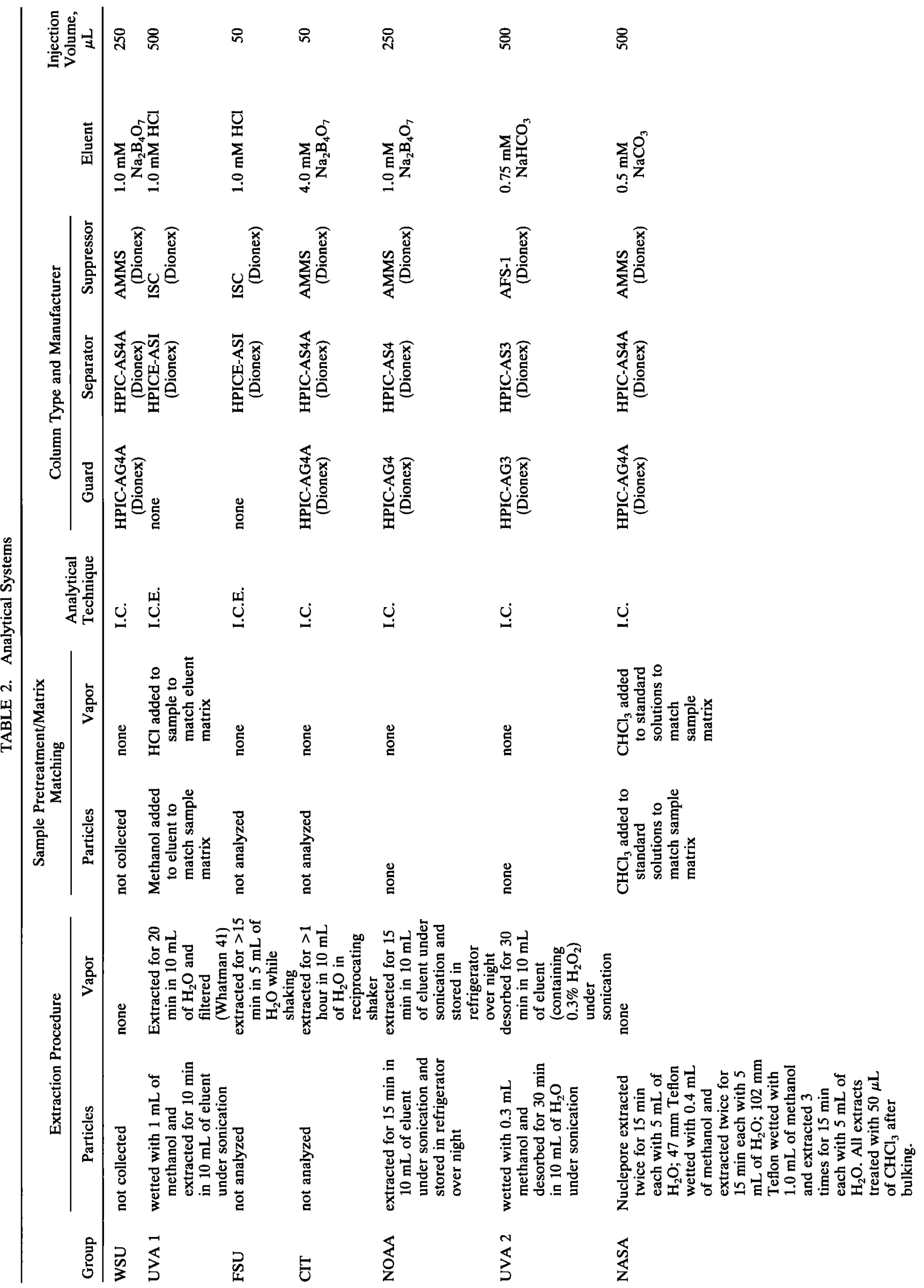


change as material accumulated on the particle filters, the hi-vol samplers were typically run for only the middle $30 \mathrm{~min}$ interval of each 1 hour sampling period.

\section{Statistical Evaluations}

Both parametric and nonparametric statistics were used to test the significance of differences between results generated by the various measurement systems. The Non-Parametric Median Test was employed to assess the null hypothesis that the independent distributions for all data sets are from populations with the same median. The Kruskas-Wallis nonparametric alternative to 1-way ANOVA tested the null hypothesis that the distributions for all data sets represent random samples from identical populations. Each data set was then compared with every other data set. The Mann-Whitney technique was applied to test the null hypothesis that each paired data set had the same distribution. The reduced major axis (RMA) procedure was subsequently used to calculate slopes and intercepts for linear regressions between each paired data set. Positive or negative artifacts were inferred if slopes or intercepts of the regressions differed significantly from 1 and 0 , respectively. Keene et al. [1986] assessed the assumptions and justified the use of this technique for testing hypotheses involving the chemical composition of atmospheric samples.

\section{Postintercomparison Experiments}

FSU and NASA performed two sets of additional experiments to identify the nature of the bias between their respective measurement systems for vapor phase species (see Results and Discussion section). The first three experiments were performed at the FSU campus in Tallahassee, Florida, on November 3-4, 1986. At the time of the experiments, the flow meters and analytical systems for the two systems were intercompared to assess any bias that might be attributable to these sources. Flow measurements agreed within $1 \%$ and analytical results within $3 \%$.

Experiment 1. $\mathrm{HCOOH}$ and $\mathrm{CH}_{3} \mathrm{COOH}$ vapor was generated by permeation cells, diluted with zero air using a Metronics Dynacalibrator 340, and delivered to a Teflon manifold where the vapor was sampled simultaneously by the two systems. Data for the long-term weight loss from the permeation cells was not available at the time of the experiment, and therefore an estimate of the concentrations of vapor species in the calibration gas stream was not obtained independent of the chemical measurements.

Experiment 2. The two systems were positioned on the roof of the Oceanography Building at FSU and simultaneously sampled ambient air for two consecutive intervals of 1 and 2 hours each.

Experiment 3. Ambient air was sampled simultaneously by two separate FSU impregnated filters. One filter sampled only ambient air while the second filter sampled ambient air with $\mathrm{CH}_{2} \mathrm{O}$ added via a permeation source to produce a gas phase concentration in the range of $400-600 \mathrm{nmol} / \mathrm{SCM}$ (approximately $10-15$ parts per billion by volume). The concentrations of $\mathrm{CH}_{2} \mathrm{O}$ in the air stream were high relative to many ambient levels reported in the literature (for example, see Duce et al. [1983] and Puxbaum et al. [1988]), and any related artifacts are expected to approach upper limits.

A second set of experiments was performed at the NASA Langley Research Center in Hampton, Virginia on November $10-11,1986$. Prior to the experiments, $\mathrm{CH}_{2} \mathrm{O}$ vapor was 
TABLE 3. Mean Detection Limits (nmol/SCM for 1 Hour Sample)

\begin{tabular}{|c|c|c|c|c|}
\hline \multirow[b]{2}{*}{ Group } & \multicolumn{2}{|c|}{ Vapor } & \multicolumn{2}{|c|}{ Particulate } \\
\hline & $\mathrm{HCOOH}$ & $\mathrm{CH}_{3} \mathrm{COOH}$ & $\mathrm{HCOOH}$ & $\mathrm{CH}_{3} \mathrm{COOH}$ \\
\hline WSU* & 0.8 & 0.7 & NA & NA \\
\hline UVA 1 & 35.5 & $\cdots$ & 1.3 & 0.6 \\
\hline \multirow[t]{2}{*}{ FSU } & 9.7 & 2.6 & 3.8 & 1.9 (coarse) \\
\hline & 247 & 421 & 1.1 & 2.0 (fine) \\
\hline $\begin{array}{l}\text { CIT } \\
\text { NOAA }\end{array}$ & $\begin{array}{r}24 / . \\
0.37\end{array}$ & $\begin{array}{l}421 \text {. } \\
\text { NR }\end{array}$ & $\begin{array}{l}\text { ND } \\
0.041\end{array}$ & $\begin{array}{l}\text { ND } \\
\text { NR }\end{array}$ \\
\hline UVA 2 & NR & NR & 2.5 & 4.8 \\
\hline \multirow{3}{*}{ NASA } & 0.88 & 1.9 & 0.17 & 0.22 (coarse) \\
\hline & & & 0.11 & 0.19 (fine) \\
\hline & & & 0.30 & 0.31 (hi-vol) \\
\hline TUW† & 2.7 & 16.1 & NA & NA \\
\hline
\end{tabular}

NA, not applicable; ND, not determined; and NR, not reported because technique was not qualitative (see Results and Discussion). Three center dots indicate high background on the resin prevented quantification of $\mathrm{CH}_{3} \mathrm{COOH}_{\mathrm{g}}$ during the short sampling periods of the intercomparison.

*Corresponds to mean dew point and temperature during intercomparison (these limits are achievable in a sampling time of approximately 10-15 min).

†Based on 2-hour sampling time.

generated by a permeation cell and supplied to a Teflon sampling manifold. The vapor phase concentration of $\mathrm{CH}_{2} \mathrm{O}$ in the sampled air was approximately $500 \mathrm{nmol} / \mathrm{SCM}$ based on data for long-term weight loss from the cell. Background levels of $\mathrm{HCOOH}$ and $\mathrm{CH}_{3} \mathrm{COOH}$ in the zero air stream to which $\mathrm{CH}_{2} \mathrm{O}$ had been added were then determined by sampling the streams with each system. Concentrations of both acids measured by FSU were below the detection limits (Table 3). For the mist chamber, $\mathrm{CH}_{3} \mathrm{COOH}$ was below the detection limit (Table 3), but $\mathrm{HCOOH}$ was found at a concentration of $3.3 \pm 0.2 \mathrm{nmol} / \mathrm{SCM}(N=4)$.

Experiment 4. Ambient air was sampled simultaneously by two mist chambers. One chamber sampled only ambient air, while a second sampled ambient air with $\mathrm{CH}_{2} \mathrm{O}$ added via a permeation source to produce a concentration of approximately $400 \mathrm{nmol} / \mathrm{SCM}$.

Experiment 5. Ambient air was sampled simultaneously by two pairs of impregnated filters. One set sampled only ambient air, while the second sampled ambient air with $\mathrm{CH}_{2} \mathrm{O}$ added at the same level as in experiment 4. Unspiked ambient air was also sampled with the mist chamber during the collection period.

Experiment 6. A final experiment was conducted to assess the effects of different storage procedures for aerosol samples. Duplicate samples were collected on Teflon filters that were then cut in half. One half of each filter was sealed separately in double polyethylene bags and stored in the dark at $4^{\circ} \mathrm{C}$. Each remaining filter half was placed in a



Fig. 1. Arrangement of sampling equipment during the intercomparison. 
TABLE 4. Mean Meteorological Conditıons During Each Sampling Interval

\begin{tabular}{|c|c|c|c|c|c|c|}
\hline Date & Time EDST & $\begin{array}{c}\text { Temperature, } \\
{ }^{\circ} \mathrm{C}\end{array}$ & $\begin{array}{l}\text { Dew } \\
\text { Point, } \\
{ }^{\circ} \mathrm{C}\end{array}$ & $\begin{array}{c}\text { Barometric } \\
\text { Pressure, } \\
\text { mbar }\end{array}$ & $\begin{array}{c}\text { Wind } \\
\text { Speed, } \\
\text { m/s }\end{array}$ & $\begin{array}{l}\text { Wind } \\
\text { Direction }\end{array}$ \\
\hline \multirow[t]{6}{*}{ June 10,1986} & $1121-1221$ & 25.7 & 13.7 & 1024. & NA & $\mathbf{S}$ \\
\hline & $1226-1326$ & 27.3 & 14.7 & 1023. & NA & SW \\
\hline & $1332-1432$ & 28.2 & 14.8 & 1023. & 0.6 & SW \\
\hline & $1437-1537$ & 28.2 & 14.6 & 1022. & $<0.5$ & SW \\
\hline & $1543-1643$ & 28.1 & 15.4 & 1021. & $<0.5$ & $\mathrm{~S}$ \\
\hline & $1647-1747$ & 26.5 & 15.4 & 1021. & $<0.5$ & $\mathbf{S}$ \\
\hline \multirow[t]{14}{*}{ June 11,1986} & $0807-0907$ & 23.0 & 17.9 & 1015 & $<0.5$ & $\mathbf{S}$ \\
\hline & $0917-1017^{*}$ & 24.4 & 18.8 & 1015 & $<0.5$ & $S$ \\
\hline & $1023-1123$ & 25.9 & 19.8 & 1015 & $<0.5$ & SW \\
\hline & $1128-1228$ & 28.1 & 20.6 & 1015. & 0.6 & $\mathrm{~S}$ \\
\hline & $1233-1333$ & 29.2 & 21.0 & 1015 & $<0.5$ & $S$ \\
\hline & $1337-1437$ & 31.3 & 21.1 & 1015 & $<0.5$ & SW \\
\hline & $1442-1542$ & 32.9 & 20.8 & 1014. & $<0.5$ & $\mathrm{~S}$ \\
\hline & $1547-1647$ & 33.4 & 20.9 & 1012. & $<0.5$ & $\mathrm{~S}$ \\
\hline & $1652-1752$ & 31.5 & 21.9 & 1011. & $<0.5$ & $\mathbf{S}$ \\
\hline & $1757-1857$ & 29.2 & 23.5 & 1011. & $<0.5$ & $S$ \\
\hline & $1903-2003$ & 28.8 & 22.5 & 1011. & 0.6 & SW \\
\hline & $2009-2019$ & 28.0 & 22.1 & 1011. & $<0.5$ & SW \\
\hline & $2115-2215$ & 26.8 & 22.1 & 1012. & $<0.5$ & SW \\
\hline & $2222-2322$ & 26.1 & 21.5 & 1012. & $<0.5$ & $\mathrm{~S}$ \\
\hline \multirow[t]{7}{*}{ June 12,1986} & $0031-0231$ & 23.9 & 21.2 & 1012. & $<0.5$ & $\mathrm{~S}$ \\
\hline & $0300-0500$ & 22.8 & 21.2 & 1011. & $<0.5$ & $\mathbf{S}$ \\
\hline & $1237-1337$ & 32.8 & 19.7 & 1011. & NA & NA \\
\hline & $1341-1442$ & 33.5 & 19.7 & 1011. & NA & NA \\
\hline & $1446-1546$ & 33.1 & 19.1 & 1010 & NA & $S$ \\
\hline & $1550-1650$ & 33.5 & 18.9 & 1009. & NA & variable \\
\hline & $1654-1754$ & 33.5 & 11.8 & 1009. & NA & $\mathbf{S}$ \\
\hline \multirow[t]{4}{*}{ June 13,1986} & 0804-0904 & 25.7 & 15.6 & 1017. & $<0.5$ & variable \\
\hline & 0909-1009 & 27.7 & 15.2 & 1017. & $<0.5$ & $S$ \\
\hline & $1015-1115$ & 28.8 & 14.9 & 1017. & $<0.5$ & SE \\
\hline & $1121-1221$ & 30.0 & 15.0 & 1018. & $<0.5$ & SW \\
\hline
\end{tabular}

NA, not available.

*'Trace amount of rain fell between 0750 and 0955 .

$+0.05 \mathrm{~cm}$ of rain fell between 1730 and 1741 .

separate Teflon centrifuge tube, sealed in a polyethylene bag, and stored in the dark at $-5^{\circ} \mathrm{C}$. Filters were stored for a period of 20 days prior to analysis. A second set of duplicate filters was collected during a different period of time, halved, and analyzed within 2 hours of collection. Results from these analyses were used to assess the variation between filter halves resulting from nonhomogeneity of blanks and samples.

\section{Results AND Discussion}

\section{Meteorological Conditions}

Meteorological conditions during the course of the intercomparison can be characterized as warm and humid with light and variable winds (Table 4). Wind speed and direction measured on the roof of Clark Hall were undoubtedly affected by the building's geometry and are not expected to be representative of surface winds in the region.

During the first day of the intercomparison (June 10), weather was dominated by a large high pressure system centered over Pennsylvania. Surface winds were predominately from the east. This system moved off shore overnight as a warm front approached Charlottesville from the west. By the morning of June 11, surface winds shifted and were now blowing from the south. The front stalled and weakened when it reached the mountains to the west of town and by midnight ceased to be an identifiable feature. Two light rain showers fell during the sampling on June 11 (Table 4). A low pressure system centered over Illinois strengthened during the morning of June 12 and began moving in an easterly direction. Surface winds shifted to the southwest as a trailing cold front from the low approached the region. By the morning of June 13, a weak depression had formed over Maryland, but surface winds were still out of the southwest. The front passed through Charlottesville at approximately 0800 hours on the morning of June 13 with an associated shift in surface winds to out of the west.

\section{Vapor Phase Species}

The concentrations of formic acid vapor $\left(\mathrm{HCOOH}_{\mathrm{g}}\right)$ and acetic acid vapor $\left(\mathrm{CH}_{3} \mathrm{COOH}_{\mathrm{g}}\right)$ measured by participating groups during the intercomparison are shown in Figures 2 and 3 , respectively. Results for all systems during the 20 hours sampling on June 11-12 indicate marked diel cycles for both species with rising concentrations during the day and falling concentrations at night. Similar cycles have been observed at Hampton, Virginia [Talbot et al., 1988] and in the Amazonian region of Brazil [Andreae et al., 1988]. Despite these general similarities, large differences existed in concentrations measured with the various techniques.

Results obtained by UVA-2 indicate that Nylasorb membranes do not retain $\mathrm{HCOOH}_{\mathrm{g}}$ or $\mathrm{CH}_{3} \mathrm{COOH}_{\mathrm{g}}$ quantitatively. Higher concentrations of both acid species were consistently found on the second of the tandem membranes, suggesting that one or more other species in the air streams either competes for collection sites or reacts with and 


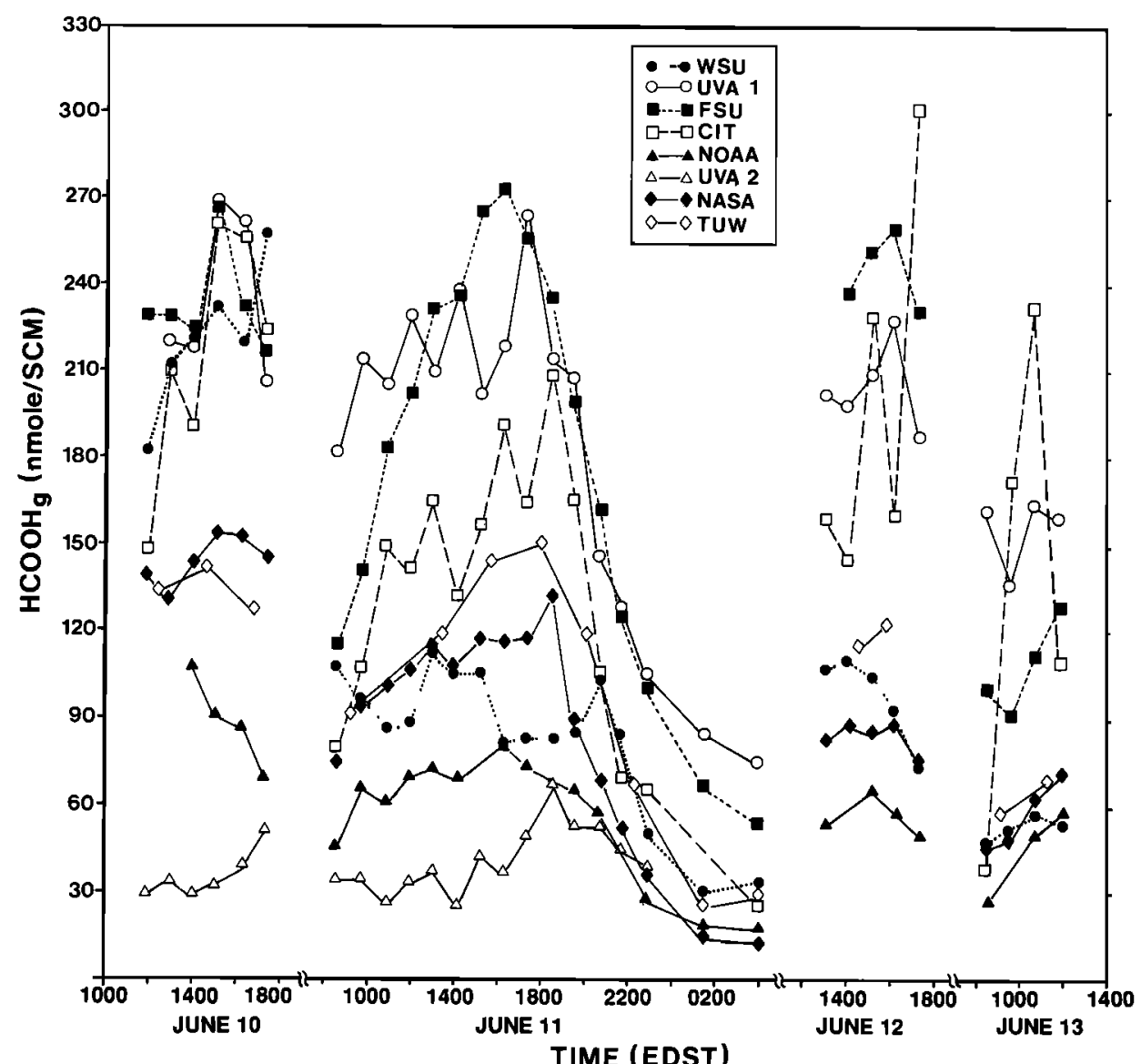

Fig. 2. Concentrations of $\mathrm{HCOOH}_{\mathbf{g}}$ measured durıng the intercomparison.

destroys part of the $\mathrm{HCOOH}_{\mathrm{g}}$ and $\mathrm{CH}_{3} \mathrm{COOH}_{\mathrm{g}}$ sorbed onto the membranes. Later field tests with a Teflon/Nylon pair situated as a prefilter for a mist chamber sampler have shown that Nylasorb membranes have poor collection efficiency for vapor phase $\mathrm{HCOOH}$ and $\mathrm{CH}_{3} \mathrm{COOH}$ (R. W. Talbot, personal communication, 1988). Results generated using Nylon membranes were therefore dropped from further evaluation.

Formic acid intercomparison. The null hypotheses that the independent distributions for all data sets were from populations with the same median and that the distributions for all data sets represent random samples from identical populations were rejected at $95 \%$ confidence. These results indicate that significant bias exists among concentrations measured by the seven remaining techniques.

Results of hypothesis tests involving the Mann-Whitney technique and the RMA procedure are summarized in Figure 4. No significant differences between results for NASA and TUW were detected. Relative to UVA 1, FSU, and CIT, however, systematic and generally significant differences in slope parameters suggest that NASA and TUW measured consistently lower concentrations of $\mathrm{HCOOH}_{\mathrm{g}}$. Systematic positive or negative artifacts can be inferred from the results between these two groups of measurement systems.

The significant differences in the slope and intercept for results generated by WSU and NASA resulted in part from significantly different concentrations of $\mathrm{HCOOH}_{\mathrm{g}}$ measured by the two systems during the six sampling periods on June 10 (Figure 2). NASA and TUW measured similar concentrations during this period. Differences between WSU, NASA, and TUW during the remainder of the intercomparison were not significant. These observations suggest that WSU or NASA and TUW may experience episodic artifacts relative to one another.

The regressions of results for UVA 1 with most other systems exhibit significant positive or negative intercepts (Figure 4) resulting in part from the high concentrations of $\mathrm{HCOOH}_{\mathrm{g}}$ measured by UVA 1 during the 4 sampling intervals on June 13. When these four measurements were removed, there were no significant differences between results for UVA 1 and FSU, and intercepts for regressions with most other systems were not significantly different from 0 . These observations suggest that the UVA 1 system may also experience episodic artifacts.

The generally low correlation coefficients for regressions of CIT results with other systems result from large variability in their field blanks. Hypothesis tests involving the distributions and the regression slope and intercept with FSU results indicate no significant differences in the 2 data sets.

NOAA measured significantly lower concentrations of $\mathrm{HCOOH}_{\mathrm{g}}$ relative to most other systems (Figures 2 and 4). Independent testing using tandem filter assemblies indicates that these differences were not associated with collection inefficiencies. We infer some type of systematic bias from these observations.

To summarize the above discussion, results of the intercomparison indicate that both systematic and episodic bias exists in the measurement of $\mathrm{HCOOH}_{\mathrm{g}}$ by the various 


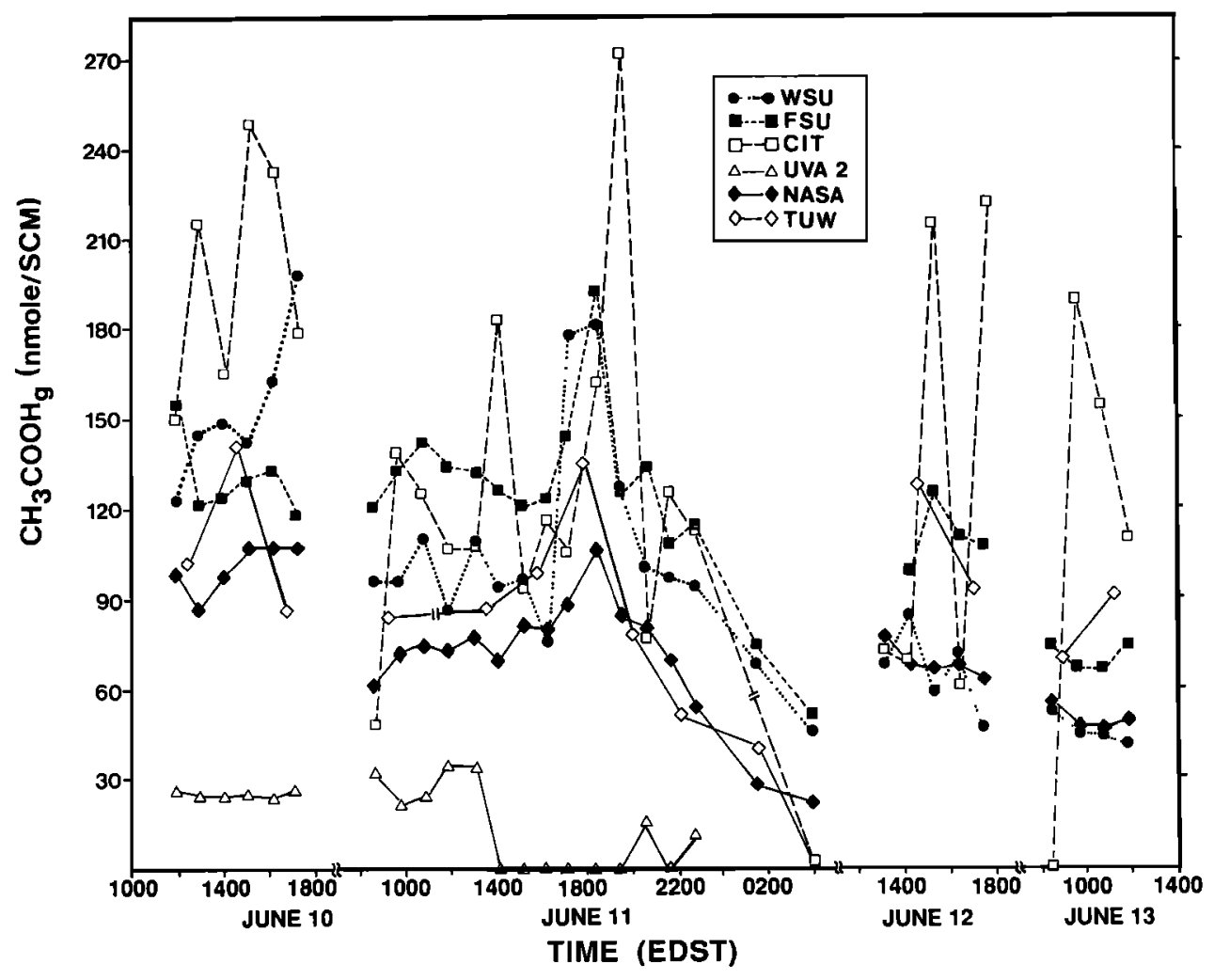

Fig. 3. Concentrations of $\mathrm{CH}_{3} \mathrm{COOH}_{\mathrm{g}}$ measured during the intercomparison.

techniques. Based on overall performance, the seven measurement systems can be roughly grouped into three categories. NASA, TUW, and WSU responded similarly to concentration changes and generally detected significantly lower concentrations of $\mathrm{HCOOH}_{\mathrm{g}}$ than did UVA 1, FSU, and CIT. Relative to the other six groups, NOAA measured consistently lower concentrations. The nature of some of these artifacts will be assessed in the section on Postintercomparison Experiments.

Acetic acid intercomparison. Five of the seven groups reported data for $\mathrm{CH}_{3} \mathrm{COOH}_{\mathrm{g}}$ during the Charlottesville intercomparison. High background levels of $\mathrm{CH}_{3} \mathrm{COOH}$ on the GC resins used by UVA 1 limited resolution for quantification of $\mathrm{CH}_{3} \mathrm{COOH}_{\mathrm{g}}$ during the 1- to 2-hour sampling

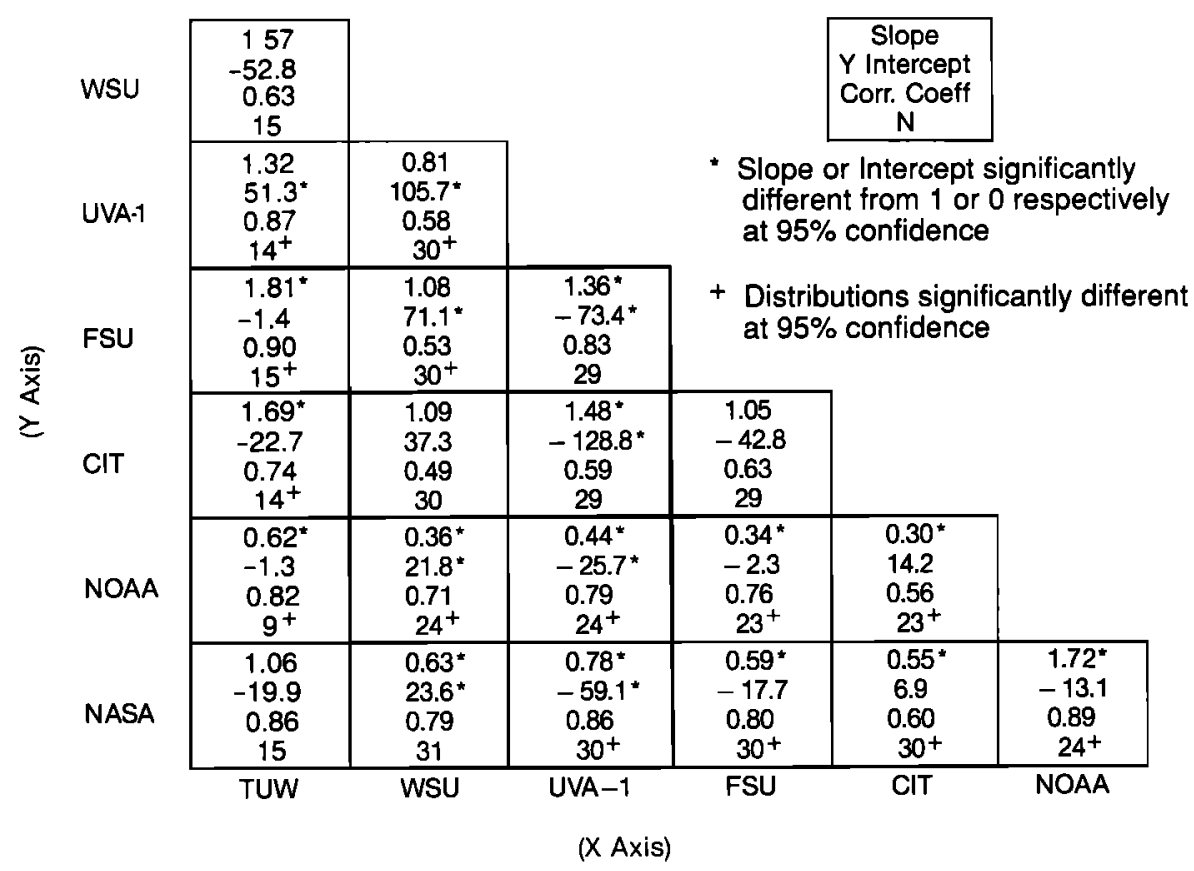

Fig. 4. Matrix of regression parameters and tests of significance for $\mathrm{HCOOH}_{\mathrm{g}}$ measured by different systems. 


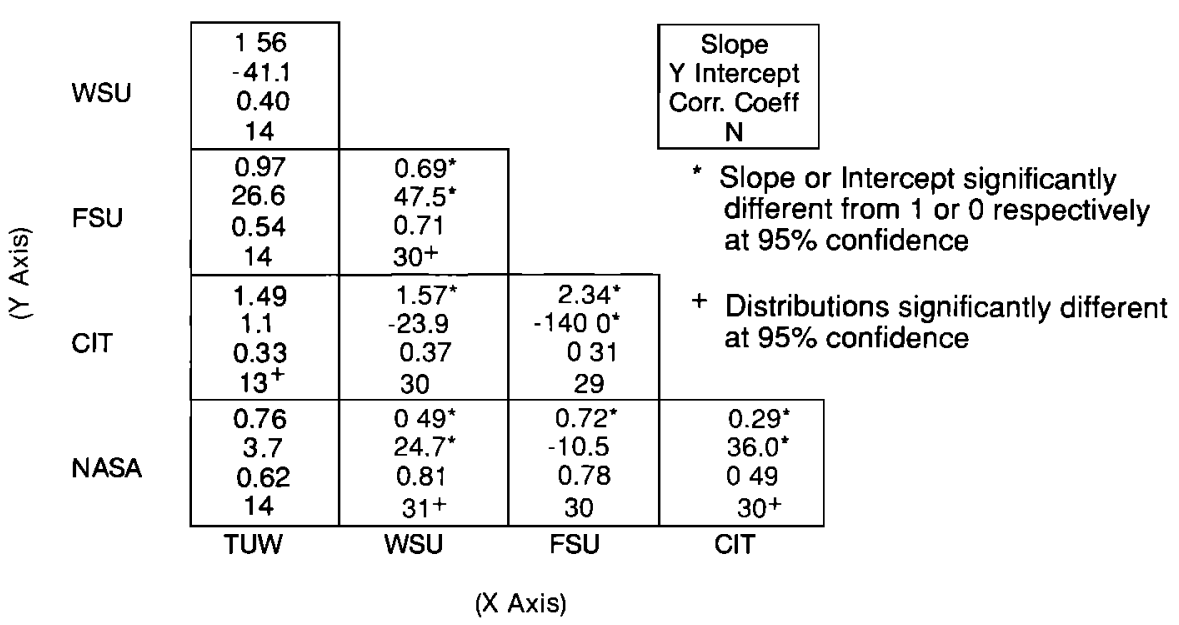

Fig. 5. Matrix of regression parameters and tests of significance for $\mathrm{CH}_{3} \mathrm{COOH}_{\mathrm{g}}$ measured by different systems.

intervals, while an analytical problem at the NOAA laboratory prevented verification of the $\mathrm{CH}_{3} \mathrm{COOH}_{\mathrm{g}}$ data generated by their measurement system. Like the data for $\mathrm{HCOOH}_{\mathrm{g}}$, there was generally poor agreement between the measurements of $\mathrm{CH}_{3} \mathrm{COOH}_{\mathrm{g}}$ by participating groups (Figure 3). Hypothesis tests for the median and distribution of all data indicated that at $95 \%$ confidence the measurements did not represent random samples from identical populations. Significant bias among the data sets is indicated by these tests.

Results of the hypothesis tests involving the MannWhitney technique and the RMA procedure are summarized in Figure 5. There were no significant differences between measurements by NASA and TUW or between those of WSU and TUW, although results for NASA and WSU were significantly different. Distributions for FSU and CIT were statistically indistinguishable, but the slope and intercept were significantly different from 1 and 0 , respectively. In general, correlation coefficients for $\mathrm{CH}_{3} \mathrm{COOH}_{\mathrm{g}}$ were lower relative to those for $\mathrm{HCOOH}_{\mathrm{g}}$ regressions.

Relative variability of formic and acetic acids. Relative variability in the concentrations of $\mathrm{HCOOH}_{\mathrm{g}}$ and $\mathrm{CH}_{3} \mathrm{COOH}_{\mathrm{g}}$ measured with various techniques (Figure 6) provides additional information with which to assess the observed bias among measurement systems. In general, FSU measured proportionately more $\mathrm{HCOOH}_{\mathrm{g}}$ compared to $\mathrm{CH}_{3} \mathrm{COOH}_{\mathrm{g}}$ relative to the other four groups. Although the absolute magnitude varies, data for both NASA and FSU suggest a diel cycle in the ratio of the two acids. Similar cycles in the atmospheric concentrations of the gases measured with the NASA mist chamber have also been observed at Hampton, Virginia [Talbot et al., 1988]. Ratios of $\mathrm{HCOOH}_{\mathrm{g}}$ to $\mathrm{CH}_{3} \mathrm{COOH}_{\mathrm{g}}$ observed by WSU show fairly consistent variability from sample to sample but a clearly discernible diel trend is not evident in the data. These patterns support results of our statistical analysis which indicated that FSU, NASA, and WSU may not be measuring exactly the same atmospheric species. The relatively fewer numbers of measurements by TUW and the greater uncertainties in the CIT data (see previous discussion) limits resolution in assessing trends in ratios of $\mathrm{HCOOH}_{\mathrm{g}}$ to $\mathrm{CH}_{3} \mathrm{COOH}_{\mathrm{g}}$ measured with those techniques.

Postintercomparison experiments. As described in the Methods section, experiments subsequent to the Charlottes- ville intercomparison evaluated the performance of the NASA mist chamber and the FSU impregnated filter system under a variety of conditions. Results of these measurements allow us to assess the nature of systematic differences between these techniques, and to speculate about the quality of measurements obtained with the other systems that were intercompared in central Virginia.

Data generated during the Tallahassee intercomparison are summarized in Table 5. Measurements with the impregnated filter and mist chamber techniques of $\mathrm{HCOOH}_{\mathrm{g}}$ in a zero air stream agreed within $10 \%$ at a concentration of approximately $150 \mathrm{nmol} / \mathrm{SCM}$ (Table 5). At a similar concentration, measurements of $\mathrm{CH}_{3} \mathrm{COOH}_{\mathrm{g}}$ with the mist chamber technique were approximately $20 \%$ higher than were those with the impregnated filter. These differences were small compared to the up to fivefold bias observed for measurements in ambient air during the Charlottesville intercomparison (Figure 2). When the two systems simultaneously sampled carboxylic acids in ambient air at Tallahassee, however, significant bias similar in magnitude to that observed in Charlottesville was detected (Table 5). Studies conducted previously indicate that the mist chamber was not subject to a negative interference [see Talbot et al., 1988]. Taken together, these results suggest that the FSU impregnated filter technique and by inference the methods used by UVA 1 and CIT, may be subject to large positive artifacts when sampling carboxylic acids in tropospheric air.

A final set of measurements was conducted at Tallahassee, to examine the effects of $\mathrm{CH}_{2} \mathrm{O}_{\mathrm{g}}$ on the quantification of $\mathrm{HCOOH}_{\mathrm{g}}$ and $\mathrm{CH}_{3} \mathrm{COOH}_{\mathrm{g}}$ with the FSU impregnated filter method. An elevation in the apparent atmospheric concentrations of both $\mathrm{HCOOH}_{\mathrm{g}}$ and $\mathrm{CH}_{3} \mathrm{COOH}_{\mathrm{g}}$ was observed in the air stream to which $\mathrm{CH}_{2} \mathrm{O}$ was added relative to unaltered ambient air (Table 5). These results indicate that $\mathrm{CH}_{2} \mathrm{O}$ may cause a positive interference in the measurement of carboxylic acids using the FSU impregnated filter technique.

Results of the intercomparison experiments conducted at NASA are summarized in Table 6. With the mist chamber technique, no significant differences were found in the concentrations of $\mathrm{HCOOH}_{\mathrm{g}}$ and $\mathrm{CH}_{3} \mathrm{COOH}_{\mathrm{g}}$ measured in ambient air with and without $\mathrm{CH}_{2} \mathrm{O}$ added (Table 6).

As observed in Tallahassee (Table 5), however, results for the FSU impregnated filter sets showed a four to fivefold increase in the concentration of $\mathrm{HCOOH}_{\mathrm{g}}$ and $\mathrm{CH}_{3} \mathrm{COOH}_{\mathrm{g}}$ 

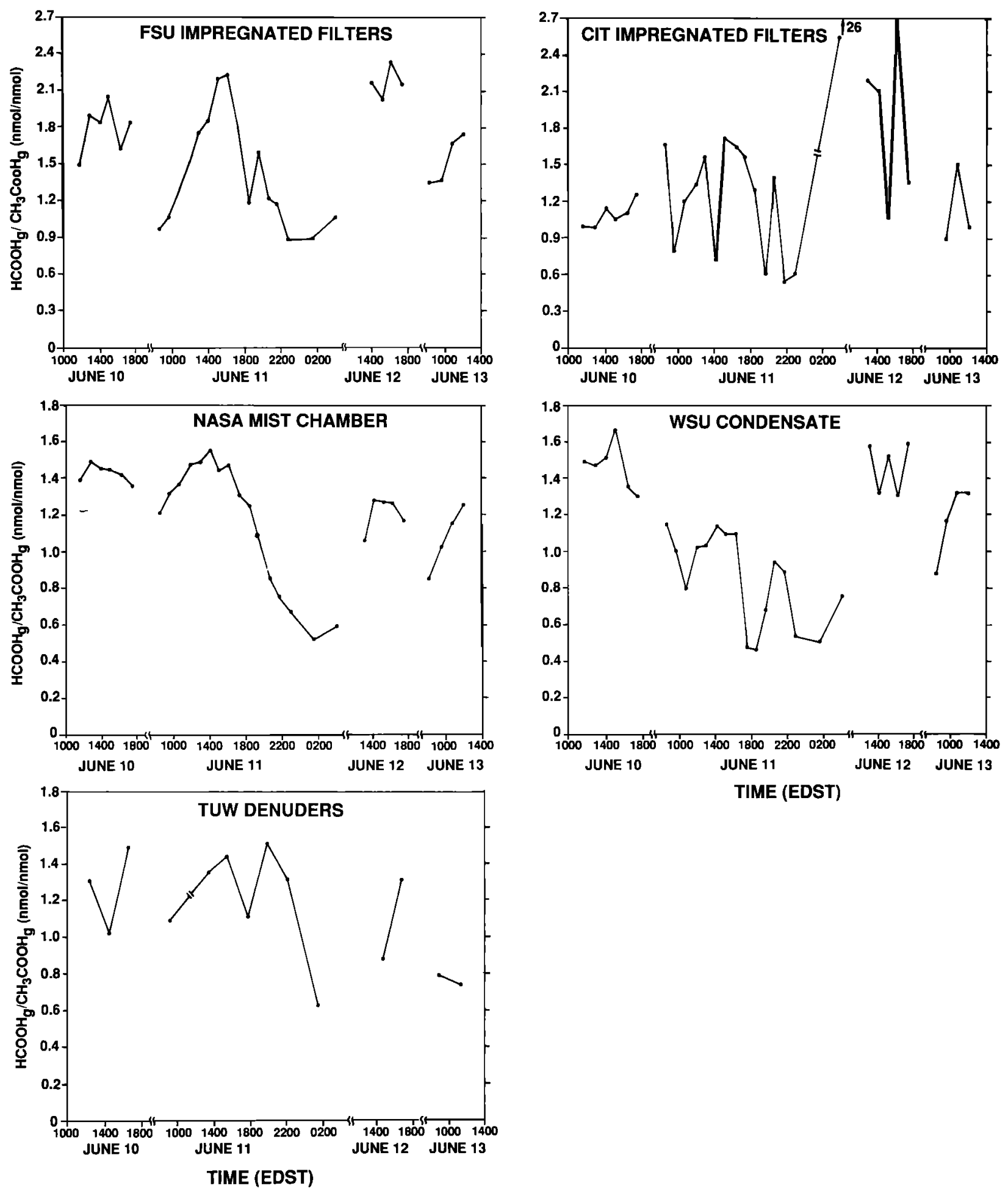

Fig. 6. Ratios of $\mathrm{HCOOH}_{\mathrm{g}}$ to $\mathrm{CH}_{3} \mathrm{COOH}_{\mathrm{g}}$ measured during the intercomparison.

determined in the air stream with $\mathrm{CH}_{2} \mathrm{O}$ added (Table 6). This positive interference occurred on both stages of the filter pack in about equal proportions for both acids. Relative to the mist chamber, measurements of $\mathrm{HCOOH}_{\mathrm{g}}$ in unaltered ambient air using the FSU impregnated filter system were a factor of 3 higher, although both techniques detected similar concentrations of $\mathrm{CH}_{3} \mathrm{COOH}_{\mathrm{g}}$. This observation suggests that the interference for the two carboxylic acids may not be directly related.
The fairly extensive experimentation completed to date has identified no significant artifacts in the measurement of $\mathrm{HCOOH}_{\mathrm{g}}$ and $\mathrm{CH}_{3} \mathrm{COOH}_{\mathrm{g}}$ using the mist chamber technique. The similarity of results obtained during the intercomparison with the TUW denuder sampler and the NASA system suggests that the denuder technique may also be free of significant artifacts. Some caution is, however, warranted when using liquid water mist or condensate to collect gaseous carboxylic acids. As acidic gases are scavenged, the $p \mathrm{H}$ of the aqueous 
TABLE 5. Summary of Results for NASA/FSU Intercomparison Conducted in Tallahassee, Florida, November 3-4, 1986

\begin{tabular}{|c|c|c|c|c|}
\hline & & $\begin{array}{l}\mathrm{HCOOH}_{\mathrm{g}}, \\
\mathrm{nmol} / \mathrm{SCM}\end{array}$ & $\begin{array}{c}\mathrm{CH}_{3} \mathrm{COOH}_{\mathrm{g}} \\
\mathrm{nmol} / \mathrm{SCM}\end{array}$ & $\mathrm{HCOOH}_{\mathrm{g}} / \mathrm{CH}_{3} \mathrm{COOH}_{\mathrm{g}}$ \\
\hline \multicolumn{5}{|c|}{ Permeation Device Intercomparison in Zero Air Stream } \\
\hline Mist chamber & $(N=6)$ & $143 \pm 3$ & $167 \pm 4$ & $0.85 \pm 0.03$ \\
\hline Impregnated filter & $(N=2)$ & $158 \pm 2$ & $136 \pm 2$ & $1.2 \pm 0.03$ \\
\hline \multicolumn{5}{|c|}{ Ambient Air Intercomparison } \\
\hline Mist chamber & (1 hour) & 27 & 24 & 1.1 \\
\hline & (2 hours) & 35 & 32 & 1.1 \\
\hline Impregnated filter & (1 hour) & 110 & 111 & 0.99 \\
\hline & (2 hours) & 114 & 65 & 1.8 \\
\hline \multicolumn{5}{|c|}{ Effects of $\mathrm{CH}_{2} \mathrm{O}$ Addition on Ambient Air Measurements With the Impregnated Filter } \\
\hline Ambient air & & 74 & 28 & 2.6 \\
\hline $\begin{array}{l}\text { Ambient air plus } \\
\mathrm{CH}_{2} \mathrm{O}\end{array}$ & & 113 & 145 & 0.78 \\
\hline
\end{tabular}

media will typically drop. This can affect the phase partitioning of $\mathrm{CH}_{3} \mathrm{COOH}$ which has a relatively high $\mathrm{pK}_{\mathrm{a}}$ of 4.76 . It is evident that for the mist chamber, long sampling intervals, particularly in regions with high concentrations of soluble acidic gases, may lead to reduced collection efficiencies. Similar problems could affect the condensate technique under conditions of low relative humidity and high concentrations of soluble acidic gases. It is also possible that aqueous phase reactions such as those involving $\mathrm{CH}_{2} \mathrm{O}, \mathrm{HCOO}^{-}$, and $\mathrm{OH}$ radicals [e.g., Jacob, 1986] could lead to positive or negative artifacts in such sampling systems. Investigators are encouraged to independently verify the performance of collection techniques involving aqueous phase media under the ambient condition in which they will be deployed.

The strong base impregnated filter techniques are prone to positive interferences in the measurement of $\mathrm{HCOOH}_{\mathrm{g}}$ and $\mathrm{CH}_{3} \mathrm{COOH}_{\mathrm{g}}$. The $\mathrm{GC}$ resin technique also appears to suffer from such artifacts. While experimental evidence suggests that atmospheric aldehydes may cause artifact $\mathrm{HCOOH}$ and $\mathrm{CH}_{3} \mathrm{COOH}$ to be produced on the alkaline filters, the exact nature of the interferences were not investigated. We do not know why the impregnated filter system operated by NOAA detected significantly lower concentrations of $\mathrm{HCOOH}_{\mathrm{g}}$ relative to the other measurement systems. We also do not know why the TUW denuder with an alkaline surface coating did not show positive interferences similar to other alkaline collection techniques.

\section{Particulate Phase Species}

Significant differences were observed between particulate phase concentrations measured by the UVA 1 hi-vol system, NOAA filter pack, and NASA hi-vol system (Figure 7). These differences may correspond to different storage procedures for filters between collection and analysis (Table 1). Immediately after collection, UVA 1 placed exposed filters in glass vials and froze them in the dark at $-4^{\circ} \mathrm{C}$ for approximately 2 months prior to analysis. NOAA placed exposed filters in polyethylene bags and refrigerated them in the dark for 7 days prior to analysis. NASA placed exposed filters in polyethylene bags and stored them in the dark at room temperature for approximately 1 month prior to analysis. These procedures may have given rise to positive or negative artifacts. The microbial transformation of dissolved $\mathrm{HCOO}_{\mathrm{T}}\left(\mathrm{HCOOH}_{\mathrm{aq}}+\mathrm{HCOO}^{-}\right)$and $\mathrm{CH}_{3} \mathrm{COO}_{\mathrm{T}}$ $\left(\mathrm{CH}_{3} \mathrm{COOH}_{\mathrm{aq}}+\mathrm{CH}_{3} \mathrm{COO}{ }^{-}\right)$is well documented for both refrigerated [e.g., Keene and Galloway, 1984] and unrefrigerated [Herlihy et al., 1987] samples of precipitation. If such a process occurred on filters, the measurements of NOAA and NASA may have underestimated ambient atmospheric concentrations, resulting in a negative artifact. Alterna-

TABLE 6. Summary of Results for NASA/FSU Intercomparison Conducted in Hampton, Virginia, November 10-11, 1986

\begin{tabular}{|c|c|c|c|}
\hline & $\begin{array}{l}\mathrm{HCOOH} \\
\mathrm{nmol} / \mathrm{SCM}\end{array}$ & $\begin{array}{l}\mathrm{CH}_{3} \mathrm{OOH}_{\mathrm{g}}, \\
\mathrm{nmol} / \mathrm{SCM}\end{array}$ & $\mathrm{HCOOH}_{\mathrm{g}} / \mathrm{CH}_{3} \mathrm{COOH}_{\mathrm{g}}$ \\
\hline \multicolumn{4}{|c|}{ Effects of $\mathrm{CH}_{2} \mathrm{O}$ Addition on Ambient Air Measurements With the Mist Chamber } \\
\hline Ambient air & 13 & 12 & 1.1 \\
\hline Ambient air plus $\mathrm{CH}_{2} \mathrm{O}$ & 14 & 12 & 1.2 \\
\hline \multicolumn{4}{|c|}{ Effects of $\mathrm{CH}_{2} \mathrm{O}$ Addition on Ambient Air Measurements With the Impregnated Filter } \\
\hline \multicolumn{4}{|c|}{ Ambient air } \\
\hline filter 1 & 16 & 15 & 1.1 \\
\hline filter 2 & 2 & 5 & 0.40 \\
\hline total & 18 & 20 & 0.90 \\
\hline \multicolumn{4}{|l|}{ Ambient air plus $\mathrm{CH}_{2} \mathrm{O}$} \\
\hline filter 1 & 71 & 51 & 1.4 \\
\hline filter 2 & 41 & 58 & 1.5 \\
\hline total & 112 & 79 & 1.4 \\
\hline \multicolumn{4}{|l|}{ Ambient air } \\
\hline mist chamber* & 6.5 & 20 & 0.33 \\
\hline
\end{tabular}

*Simultaneously measured with impregnated filters. 
Particulate $\mathrm{HCOO}_{\mathrm{T}}(\mathrm{N}=27)$

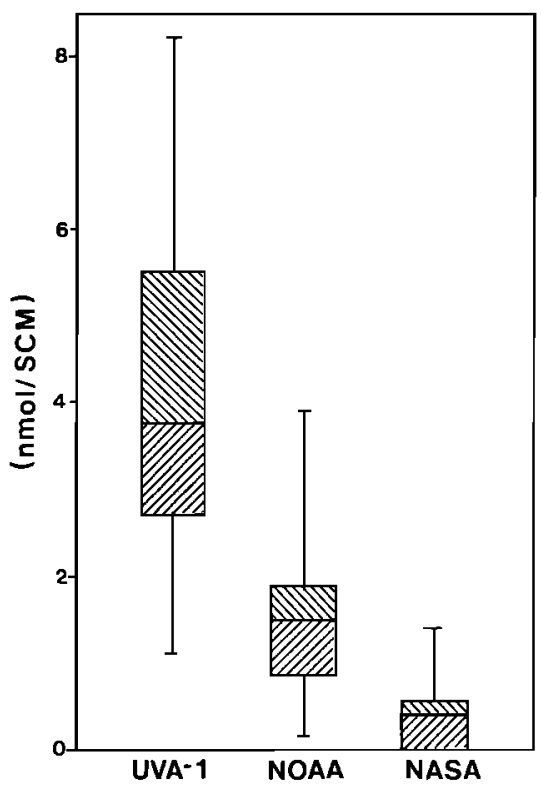

Particulate $\mathrm{CH}_{3} \mathrm{COO}_{\mathrm{T}}(\mathrm{N}=30)$

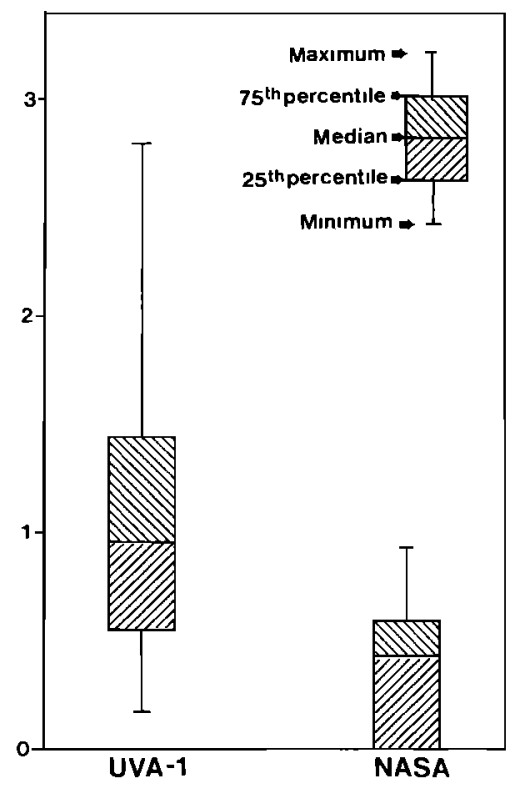

Fig. 7. Distributions for concentrations of particulate $\mathrm{HCOO}_{\mathrm{T}}$ and $\mathrm{CH}_{3} \mathrm{COO}_{\mathrm{T}}$ measured by the UVA 1 hi-vol, the NOAA filter pack, and the NASA hi-vol systems.

tively, the freezing procedure of UVA 1 may have ruptured natural biogenic aerosols such as pollen which could release $\mathrm{HCOO}_{\mathrm{T}}$ and $\mathrm{CH}_{3} \mathrm{COO}_{\mathrm{T}}$ resulting in a positive artifact. Differences in extraction procedures may have also contributed to the observed variability. Sonification which was used by UVA 1 and NOAA but not by NASA also could have ruptured biogenic aerosols or facilitate the aqueous phase production of $\mathrm{HCOOH}$ and $\mathrm{CH}_{3} \mathrm{COOH}$ from decomposition of organic compounds resulting in apparently higher atmospheric concentrations. Additional experimentation is needed to resolve the nature of bias in the measurements of particulate phase carboxylic acids.

The results of the stacked filter pack which was operated by NASA are summarized in Table 7. As previously discussed, the interpretation of these data is complicated by the potential for artifacts. In general, however, higher total concentrations of particulate $\mathrm{HCOO}_{\mathrm{T}}$ and $\mathrm{CH}_{3} \mathrm{COO}_{\mathrm{T}}$ were measured by NASA using the lo-vol stacked filter pack relative to the hi-vol sampler (Figure 7). Such an effect could be explained by the larger pressure drop across the hi-vol filter resulting in volatilization of vapor from aerosols. Additional experimentation is needed to assess the potential for and magnitude of such an effect.
Results of the storage experiment conducted by NASA subsequent to the Charlottesville intercomparison are summarized in Table 8. For samples which were analyzed immediately after collection, mean variations between filter halves of 17 and $34 \%$ for $\mathrm{HCOO}_{\mathrm{T}}$ and $\mathrm{CH}_{3} \mathrm{COO}_{\mathrm{T}}$ were observed. The frozen samples yielded mean concentrations of $\mathrm{HCOO}_{\mathrm{T}}$ and $\mathrm{CH}_{3} \mathrm{COO}_{\mathrm{T}}$ which were 56 and $60 \%$, respectively, higher than their refrigerated counterparts. These results suggest that $\mathrm{HCOO}_{\mathrm{T}}$ and $\mathrm{CH}_{3} \mathrm{COO}_{\mathrm{T}}$ were either lost from the refrigerated samples, most likely via biological degradation, or that the frozen process ruptured aerosol particles releasing additional amounts of carboxylic compounds.

The results of these intercomparisons indicate that procedures for sample collection, storage, and extraction may result in positive or negative artifacts in the measurement of particulate phase concentrations. Unfortunately, because sections of stored filters were not analyzed immediately after collection of particles, definitive information is not available to critically assess the nature of these artifacts. As such, we encourage other investigators to perform carefully designed experiments which will resolve these issues prior to reporting concentration for particulate phase carboxylic species.

TABLE 7. NASA Stacked Filter Pack

\begin{tabular}{|c|c|c|c|c|c|c|c|c|}
\hline \multirow[b]{2}{*}{ Date } & \multirow[b]{2}{*}{ Time On } & \multirow[b]{2}{*}{ Time Off } & \multicolumn{2}{|c|}{ Coarse } & \multicolumn{2}{|c|}{ Fine } & \multicolumn{2}{|c|}{ Total } \\
\hline & & & $\mathrm{HCOO}_{\mathrm{T}}$ & $\mathrm{CH}_{3} \mathrm{COO}_{\mathrm{T}}$ & $\mathrm{HCOO}_{\mathrm{T}}$ & $\mathrm{CH}_{3} \mathrm{COO}_{\mathrm{T}}$ & $\mathrm{HCOO}_{\mathrm{T}}$ & $\mathrm{CH}_{3} \mathrm{COO}_{\mathrm{T}}$ \\
\hline June 10 & 1155 & 1755 & 1.5 & 0.44 & 0.41 & 0.47 & 1.9 & 0.91 \\
\hline \multirow[t]{5}{*}{ June 11} & 0815 & 1026 & $\cdots$ & 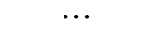 & .. & $\cdots$ & $\cdots$ & \\
\hline & 0951 & 1254 & 0.99 & 0.24 & 0.49 & 0.57 & 1.5 & 0.81 \\
\hline & 1300 & 1730 & 0.74 & $<0.67$ & 0.36 & 0.62 & 1.1 & 0.62 \\
\hline & 1806 & 1838 & $\cdots$ & $\cdots$ & $\cdots$ & $\cdots$ & 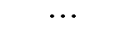 & 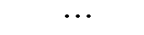 \\
\hline & 1846 & 2314 & 0.42 & $<0.39$ & 0.75 & 0.98 & 1.2 & 0.98 \\
\hline \multirow[t]{2}{*}{ June 12} & 0000 & 0500 & $<0.32$ & $<0.24$ & 0.35 & 0.86 & 0.35 & 0.86 \\
\hline & 1251 & 1751 & 1.2 & 0.30 & 0.54 & 0.56 & 1.7 & 0.86 \\
\hline June 13 & 0652 & 1222 & 1.5 & 0.44 & 0.22 & $<0.82$ & 1.7 & 0.44 \\
\hline
\end{tabular}

Values are given in nmol/SCM. Coarse, $>1.5 \mu \mathrm{m}$; fine, $<1.5 \mu \mathrm{m}$. 
TABLE 8. Results of Storage Experiment for Particulate Phase $\mathrm{HCOO}_{\mathrm{T}}$ and $\mathrm{CH}_{3} \mathrm{COO}_{\mathrm{T}}$

\begin{tabular}{lccccr}
\hline & \multicolumn{2}{c}{ Filter I Halves } & & \multicolumn{2}{c}{ Filter 2 Halves } \\
\cline { 2 - 3 } \cline { 5 - 6 } & $\mathrm{A}$ & $\mathrm{B}$ & $\mathrm{A}$ & $\mathrm{B}$ \\
\hline \multirow{5}{*}{ No Storage: Immediate } & Analysis \\
$\mathrm{HCOO}_{\mathrm{T}}$ & 0.15 & 0.20 & 0.21 & 0.23 \\
$\mathrm{CH}_{3} \mathrm{COO}_{\mathrm{T}}$ & 0.06 & 0.14 & 0.18 & 0.20 \\
\multicolumn{5}{c}{ Storage: 20 Days } \\
$\mathrm{HCOO}_{\mathrm{T}}$ & 0.38 & 1.1 & & \\
$\mathrm{CH}_{3} \mathrm{COO}_{\mathrm{T}}$ & 0.14 & 0.37 & 0.50 & 0.91 \\
\hline
\end{tabular}

The filter pairs that were analyzed immediately after collection were not simultaneously collected with those that were stored for 20 days prior to analysis. Storage conditions: A, Sealed in double polyethylene bags and stored at $4^{\circ} \mathrm{C}$ in the dark; $\mathrm{B}$, placed in a Teflon centrifuge tube, sealed in a polyethylene bag, and stored at $-5^{\circ} \mathrm{C}$ in the dark (frozen). Atmospheric concentrations are given in $\mathrm{nmol} / \mathrm{SCM}$. Sampling period was 4 hours. Estimated detection limits are $0.06 \mathrm{nmol} / \mathrm{SCM}$ for $\mathrm{HCOO}_{\mathrm{T}}$ and $0.04 \mathrm{nmol} / \mathrm{SCM}$ for $\mathrm{CH}_{3} \mathrm{COO}_{\mathrm{T}}$.

Until such investigations are carried out, particulate phase data must be viewed with caution and an appreciation of potential limitations.

\section{Intercalibrations of Analytical Techniques}

Analytical intercalibrations typically agreed within approximately $\pm 10 \%$ or $\pm 1 \mu \mathrm{mol} / \mathrm{L}$ of expected values (Table 9). These differences are small compared to the overall differences between results generated by participating groups. The observed differences between the various techniques appear to originate primarily from the specificity of sampling media, handling, or storage rather than with analytical bias.

Several additional factors not addressed by such an intercalibration should also be considered. The majority of participating groups used standard ion chromatography (IC) to analyze their -samples (Table 2). However, IC techniques frequently do not discriminate definitively between lactate $\left(\mathrm{CH}_{3} \mathrm{CHOHCOO}{ }_{\mathrm{T}}\right)$ and $\mathrm{CH}_{3} \mathrm{COO}_{\mathbf{T}}(\mathrm{K}$. Rice, Dionex Corporation, personal communication, 1988). $\mathrm{CH}_{3} \mathrm{CHOHCOO}_{\mathrm{T}}$ has been observed in atmospheric samples by a number of investigators (see, for example, Keene et al. [1983] and Likens et al. [1983], among others) and could represent a significant source of bias in some regions. Investigators are encouraged to verify their measurements of $\mathrm{CH}_{3} \mathrm{COOH}$ by intercomparing with results generated by a specific analytical technique such as Ion Exclusion Chromatography (ICE).

Peroxyacetyl nitrate (PAN) is also a potential interferent in measurements of $\mathrm{CH}_{3} \mathrm{COOH}$. PAN hydrolyzes to give $\mathrm{CH}_{3} \mathrm{COO}^{-}$and $\mathrm{NO}_{2}^{-}$in alkaline solutions such as the water film on base impregnated filters or the basic eluents used in IC. Although PAN levels were probably low compared to carboxylic acids during the Charlottesville intercomparison, such an artifact could be significant in more polluted environments.

\section{Conclusions}

1. Nylasorb membranes did not retain $\mathrm{HCOOH}_{\mathrm{g}}$ or $\mathrm{CH}_{3} \mathrm{COOH}_{\mathrm{g}}$ quantitatively. Evidence suggests that other atmospheric constituents either compete for collection sites or react with and destroy $\mathrm{HCOOH}_{\mathrm{g}}$ and $\mathrm{CH}_{3} \mathrm{COOH}_{\mathrm{g}}$ collected on the membranes.

2. Significant systematic and episodic artifacts exist among many currently deployed measurement systems for $\mathrm{HCOOH}_{\mathrm{g}}$ and $\mathrm{CH}_{3} \mathrm{COOH}_{\mathrm{g}}$.

3. Based on previously published data [Talbot et al., 1988] and on results generated during this study, no significant positive or negative interferences were found for the NASA mist chamber technique. Thermodynamic considerations suggest, however, that caution should be exercised when using this and other techniques involving aqueous phase media to collect carboxylic acids.

4. There were no significant differences between results generated by the NASA mist chamber and the TUW denuder collection system, suggesting that the denuder technique is also free of positive or negative interferences in the measurement of $\mathrm{HCOOH}_{\mathrm{g}}$ and $\mathrm{CH}_{3} \mathrm{COOH}_{\mathrm{g}}$.

5. Evidence for significant episodic artifacts in the measurement of $\mathrm{HCOOH}_{\mathrm{g}}$ was observed between the condensate technique and the mist chamber. Similar, though not significant, differences were observed between results for the condensate technique and the denuder system.

TABLE 9. Intercalibration of Analytical Techniques

\begin{tabular}{|c|c|c|c|c|}
\hline \multirow[b]{2}{*}{ Group } & \multicolumn{2}{|c|}{ Aliquot 1} & \multicolumn{2}{|c|}{ Aliquot 2} \\
\hline & $\underset{\mu \mathrm{mol} / \mathrm{L}}{\mathrm{HCOO}_{\mathrm{T}}}$ & $\begin{array}{c}\mathrm{CH}_{3} \mathrm{COO}_{\mathrm{T}}, \\
\mu \mathrm{mol} / \mathrm{L}\end{array}$ & $\begin{array}{c}\mathrm{HCOO}_{\mathrm{T}} \\
\mu \mathrm{mol} / \mathrm{L}\end{array}$ & $\underset{\mu \mathrm{mol} / \mathrm{L}}{\mathrm{CH}_{3} \mathrm{COO}_{\mathrm{T}}}$ \\
\hline WSU & 22.7 & 25.4 & 1.2 & 1.27 \\
\hline UVA 1 & 23.2 & 25.5 & 0.65 & 2.08 \\
\hline FSU & 23.8 & 25.9 & 1.32 & 2.30 \\
\hline CIT & 22.7 & 25.3 & BLD & BLD \\
\hline NOAA & 27. & NR & 1.33 & \\
\hline UVA 2 & $25.1 *$ & $21.1^{*}$ & 0.71 & 1.66 \\
\hline NASA & 24.4 & 27.1 & 1.26 & 2.37 \\
\hline TUW & 24.9 & 24. & BLD & BLD \\
\hline $\bar{X} \pm \mathrm{SD}$ & $24.2 \pm 1.46$ & $24.9 \pm 1.91$ & $1.08 \pm 0.313$ & $1.94 \pm 0.464$ \\
\hline $\begin{array}{l}\text { Expected } \\
\text { concentrations } \\
\text { of test } \\
\text { solutions }\end{array}$ & 23.1 & 25.2 & 1.10 & 1.68 \\
\hline
\end{tabular}

NR, values not reported; BLD, concentration below detection limit.

*Test solutions diluted into lower analytical range. Reported concentrations reflect proportionately larger uncertainties. 
6. Alkaline filter techniques and the GC resin technique are prone to large positive interferences in the measurement of $\mathrm{HCOOH}_{\mathrm{g}}$ apparently resulting in part from reactions of aldehydes with the sampling media to generate $\mathrm{HCOOH}$ subsequent to collection. Aldehyde additions to ambient air streams also resulted in the generation of artifact $\mathrm{CH}_{3} \mathrm{COOH}$ on impregnated filter system operated by FSU.

7. Significant bias was observed for particulate phase measurements by participating groups, and it appeared to arise from differences in sample storage and handling subsequent to collection. Experimental evidence was not available to assess the nature of these artifacts.

8. Analytical bias could account for only a minor fraction $(<10 \%)$ of the observed differences (up to a factor of 5) between results obtained with the various techniques that were intercompared.

Acknowledgments. We thank all participants in the intercomparison for contributing to an intellectually stimulating and thoroughly enjoyable experience. We especially thank Elizabeth Partin, Judy Hurt, and Ming Siu for their tireless assistance before, during, and after the sampling in Charlottesville. Jennie Moody and Mark Hawley offered helpful suggestions concerning statistical evaluations and Dan Smith assisted with computer-related calculatıons. Joseph Tokos and two anonymous reviewers contributed constructive comments. We also gratefully acknowledge Brenda W. Morris for her help and pattence in preparing the manuscript. This research was funded as part of the National Acid Precipitation Assessment Program by the National Oceanic and Atmospheric Administration and the Department of Energy. Additional funding was provided by the Austrian Science Foundation (Project P5693). The Academic Computing Center of the University of Virginia, Charlottesville, provided computer facilities for data reduction. This is a contribution to the Global Precipitation Chemistry Project, the Western Atlantıc Ocean Experıment, and the MAP3S Precipitation Chemistry Program.

\section{REFERENCES}

Andreae, M. O., R. W. Talbot, T. W. Andreae, and R. C. Harriss, Formic and acetic acids over the central Amazon region, Brazil, 1, Dry season, J. Geophys. Res., 93, 1616-1624, 1988.

Anlauf, K. G., P. Fellin, H. A. Wiebe, H. I. Schiff, G. I. Mackay, R. S. Braman, and R. Gilbert, A comparison of three methods for measurement of atmospheric nitric acid and aerosol nitrate and ammonium, Atmos. Environ., 19, 325-333, 1985.

Chameides, W. L., and D. D. Davis, Aqueous-phase source for formic acid in clouds, Nature, 304, 427-429, 1983.

Cofer, W. R. III, V. G. Collins, and R. W. Talbot, Impregnated aqueous scrubber for collection of soluble atmospheric trace gases, Environ. Sci. Technol., 19, 557-560, 1985.

Currie, L. A., Limits for qualitative detection and quantitative determination: Application to radiochemistry, Anal. Chem., 40, $586-593,1968$.

Dawson, G. A., and J. C. Farmer, Soluble atmospheric trace gases in the Southwestern United States, 2, Organic species HCHO, $\mathrm{HCOOH}, \mathrm{CH}_{3} \mathrm{COOH}, J$. Geophys. Res. 93(5), 5200-5206, 1988.

Duce, R. A., V. A. Mohnen, P. R. Zimmerman, D. Grosjean, W. Cautreels, R. Chatfield, R. Jaenicke, J. A. Ogren, E. D. Pellizzari, and G. T. Wallace, Organic material in the global troposphere, Rev. Geophys., 21, 921-952, 1983.

Farmer, J. C., and G. A. Dawson, Condensate sampling of soluble atmospheric trace gases, J. Geophys. Res., 87, 8931-8942, 1982.

Fehsenfeld, F. C., et al., A ground-based intercomparison of NO, $\mathrm{NO}_{\mathrm{x}}$ and $\mathrm{NO}_{\mathrm{y}}$ measurement techniques, J. Geophys. Res., 92, 14,710-14,722, 1987.

Haynes, D. L., Collection of formic acid vapor and analysis by ion chromatography, in Ion Chromatographic Analysis of Environmental Pollutants, vol. 2, edited by J. D. Nulnik and E. Sawickı, pp. 157-169, Butterworths, Stoneham, Mass., 1979.

Herlihy, L. J., J. N. Galloway, and A. L. Mills, Bacterial utilization of formic and acetic acid in rainwater, Almos. Environ., 21. 2397-2402, 1987.
Hoell, J. M., Jr., G. L. Gregory, D. S. McDougal, M. A. Carroll, M. McFarland, B. A. Ridley, D. D. Davis, J. Bradshaw, M. O. Rodgers, and A. L. Torres, An intercomparison of nitric oxide measurement techniques, J. Geophys. Res., 90, 12,843-12,851, 1985.

Jacob, D. J., The chemistry of $\mathrm{OH}$ in remote clouds and its role in the production of formic acid and peroxymonosulfate, J. Geophys. Res., 91, 9807-9826, 1986.

Jacob, D. J., and S. C. Wofsy, Photochemistry of biogenic emissions over the Amazon Forest, J. Geophys. Res., 93, 1477-1486, 1988.

John, W., S. Hering, G. Reischl, G. Sasaki, and S. Goren, Characteristics of Nuclepore filters with large pore size, II, Filtration properties, Atmos. Environ., 17, 373-382, 1983.

Keene, W. C., and J. N. Galloway, Organic acidity in precipitation of North America, Atmos. Environ., 18, 2491-2497, 1984.

Keene, W. C., and J. N. Galloway, Considerations regarding sources for formic and acetic acids in the troposphere, J. Geophys. Res., 91, 14,466-14,474, 1986.

Keene, W. C., J. N. Galloway, and J. D. Holden, Jr., Measurement of weak organic acidity in precipitation from remote areas of the world, J. Geophys. Res., 88, 5122-5130, 1983.

Keene, W. C., A. A. P. Pszenny, J. N. Galloway, and M. E. Hawley, Sea-salt corrections and interpretation of constituent ratios in marine precipitation, J. Geophys. Res., 9/, 6647-6658, 1986.

Likens, G. E., E. S. Edgerton, and J. N. Galloway, The composition and deposition of organic carbon in precipitation, Tellus, Ser. $B, 35,16-24,1983$.

Mulawa, P. A., and S. H. Cadle, A comparison of nitric acid and particulate nitrate measurements by the penetration and denuder difference methods. Atmos. Environ., 19, 1317-1324, 1985.

Puxbaum, H., C. Rosenberg, M. Gregori, C. Lanzerstorfer, E. Ober, and W. Winiwarter, Atmospheric concentrations of formic acid and acetic acid and related compounds in eastern and northern Austria, Atmos. Environ., 22, 2841-2850, 1988.

Rosenberg, C., W. Wıniwarter, M. Gregori, G. Pech, V. Casensky, and $\mathrm{H}$. Puxbaum, Determination of inorganıc and organic volatile acids, $\mathrm{NH}_{2}$, particulate $\mathrm{SO}_{4}^{--}, \mathrm{NO}_{3}^{-}$, and $\mathrm{Cl}^{-}$in ambient air with an annular diffusion denuder system, Fresenus $Z$. Anal. Chem., $331,1-7,1988$.

Talbot, R. W., K. M. Steın, R. C. Harriss, and W. R. Cofer, III, Atmospheric geochemistry of formic and acetic acids at a midlatıtude temporate site, J. Geophys. Res., 93, 1638-1652, 1988.

Weathers, K. C., et al., Cloud water chemistry from ten sites in North America, Environ. Sci. Technol., 22, 1018-1026, 1988.

M. O. Andreae, Max-Planck-Institute for Chemistry, Postfach 3060, D-6500 Mainz, Federal Republic of Germany.

K. Beecher, Atmospheric Sciences Division, NASA Langley Research Center, Hampton, VA 23665.

H. Berresheim, School of Geophysical Sciences, Georgia Institute of Technology, Atlanta GA 30332.

M. Castro, J. N. Galloway, W. C. Keene, and J. R. Maben, Department of Environmental Sciences, Clark Hall, University of Virginia, Charlottesville, VA 22903.

J. C. Farmer and H. Westberg, Laboratory for Atmospheric Research, Washington State University, Pullman, WA 99164.

M. R. Hoffmann and J. W. Munger, Environmental Engineering Sciences, California Institute of Technology, Pasadena, CA 91125.

S-M. Li, Department of Oceanography, Florida State University, Tallahassee, FL 32306.

R. B. Norton, Aeronomy Laboratory, National Oceanic and Atmospheric Administration, Boulder, CO 80303.

H. Puxbaum and W. Winiwarter, Institute for Analytical Chemistry, Technical University of Vienna, A-1060 Vienna, Austria.

A. A. P. Pszenny, Atlantic Oceanographic and Meteorological Laboratories, National Oceanic and Atmospheric Administration, Miami, FL 33149.

R. W. Talbot, Complex Systems Research Center, University of New Hampshire, Durham, NH 03824.

(Received June 15, 1988; revised January 13, 1989; accepted January 31, 1989.) 